\title{
Biological Activities of Deshistidine-glucagon
}

\section{Yoshio IKEDA, Norio OBAYASHI, Hiroshi SAITO, Yasuhiko MATSUURA, Takashi SANO and Tomio TANESE}

4th Department of Internal Medicin, Jikei University School of Medicine, Tokyo, Director Masakazu Abe

The biological activities of deshistidine-glucagon (DH-glucagon) which was prepared by removal of a N-terminal aminoacid, histidine, from glucagon were compared both in vitro and in vivo experiments with those of native glucagon. DH-glucagon was supplied from Novo laboratories. The results of the experiments obtained were as follows:

1) DH-glucagon (in an amount of $30 \mu \mathrm{g}$ ) lacked the blood-sugar increasing action due to the glycogenolysis after intraperitoneal administration in rats.

2) Increase of the glucose uptake by the epididymal adipose tissue of a rat could not be found in a in vitro experiment in the presence of $\mathrm{DH}$-glucagon in an amount of $0.1 \mu \mathrm{g}$ to $10.0 \mu \mathrm{g} / \mathrm{ml}$

3) Lypolysis increasing action of DH-glucagon (in an amount of $0.1 \mu \mathrm{g}$ to $10.0 \mu \mathrm{g} / \mathrm{ml}$ ) as indicated by the release of glycerol in vitro was also apparently absent as compared to that of glucagon.

From the above results the biological activities of DH-glucagon were discussed.

(See pp. 605 607) 


\section{Deshistidine-glucagon の生物活性について}

慈恵医科大学 阿部内科
池 田 義 雄, 尾 林 紀 雄
斉 藤
浩, 松 浦 晴 彦

(昭和 46 年 9 月 23 日受付)

Glucagon からN末端アミノ酸である Histidine をとりのぞいた Deshistidine-glucagon (DH-glucagon)について, その生物活性を, in vivo と in vitro で Native-glucagon のそれと比較検討した. DH-glucagon をラットの腹腔内に投与したさいの血糖上昇作用および DH-glucagon を in vitro 亿添 加したさいの，ラット副紊丸脂肪組織へのブドウ糖のとりとみ, medium 中への Glycerol 放出は Glucagon と比較して明らかに欠如した。 てのように DH-glucagon には Glucagon にみられるような活 性の認められないととを示唆した。

Glucagon からその N末端アミノ酸である Histidine をとりのぞいた Deshistidine-glucagon (DH-glucagon）についてその生物活性を in vivo そ in vitro で, Native glucagon のそれと比較検討した.

\section{材 料と方 法}

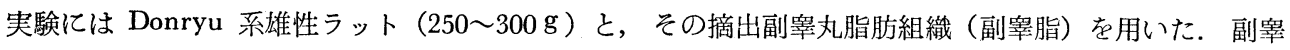
脂法の概要は既報の如くである ${ }^{1)}$.

5 匹を一群としたラットの腹腔内に DH-glucagon $30 \mu \mathrm{g}$ を投与して DH-glucagon の血糖におよぼす影 響を経時的に観察した。対照には等量の生理食塩水投与群と, glucagon $30 \mu \mathrm{g}$ 投与群をおいた。

ラットの副輧脂を用いた in vitro の実験では, DH-glucagon を添加したさいのブドウ糖とり込み (Glucose uptake) におよぼす影響と，Glycerol 放出を指標とした脂肪異化作用におよぼす影響とについて， glucagon との比較の上で観察した.

実験に用いた DH-glucagon, と glucagon はいずれも NOVO 研究所より小玉株式会社を通じて供与さ れたものである.

\section{実 験 成 績}

\section{DH-glucagon の血糖におよぼす影響}

図 1 は, DH-glucagon $30 \mu \mathrm{g} / 0.3 \mathrm{ml}$, glucagon $30 \mu \mathrm{g} / 0.3 \mathrm{ml}$, そして等量の生理食塩水のそれぞれを, ラッ 卜腹腔内に投与した前後の血糖値の変動を示したものである. 血糖值は 5 匹を一群としたさいの平均值で示 されている.

Glucagon の投与により血糖は速やかに上昇し，15分後に頂值を示した. てれに対して DH-glucagon で は血糖上昇がみられず，生理食塩水投与ラットとの間になんら有意差を認めなかつた。すなわち DH-glucagon はラットの腹腔内投与後の糖原分解による血糖上昇作用を欠如するといら成績である.

\section{DH-glucagon のラット副睪脂の Glucose uptake におよぼす影響}

ラット副辠脂を用いる in vitro の実験で，glucagon 添加は Glucose uptake を著明に高める作用のあ 
Fig. 1. Hyperglycemic effect of deshistidineglucagon

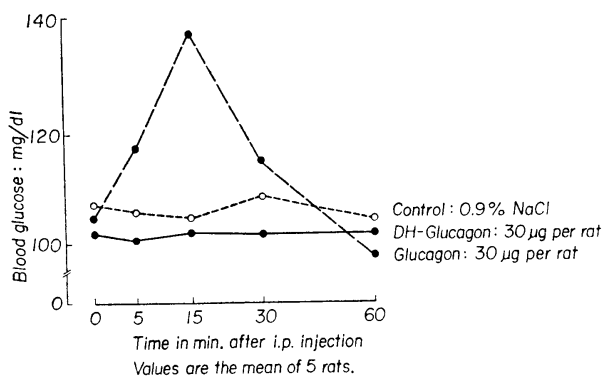

るととが分かつた.

図 2 の白いバーは glucagon $0.1 \mu \mathrm{g} / \mathrm{ml}, 1.0 \mu \mathrm{g} / \mathrm{ml}$, $10.0 \mu \mathrm{g} / \mathrm{ml}$ を，それぞれ添加したさいの Glucose uptake である. いずれの濃度においても，対照よ りも有意な Glucose uptake の促進がえられてい る.

これに対して,斜線のバーで示した DH-glucagon $0.1 \mu \mathrm{g} / \mathrm{ml}, 1.0 \mu \mathrm{g} / \mathrm{ml}, 10.0 \mu \mathrm{g} / \mathrm{ml}$ の各濃度によつて は, Glucose uptake の促進を認めることができなか つた.

3. DH-glucagon のラット副睪脂の脂肪異化に およぼす影鮫

Fig. 2. Effect of deshistidine-glucagon on glucose uptake of isolated rat adipose tissue

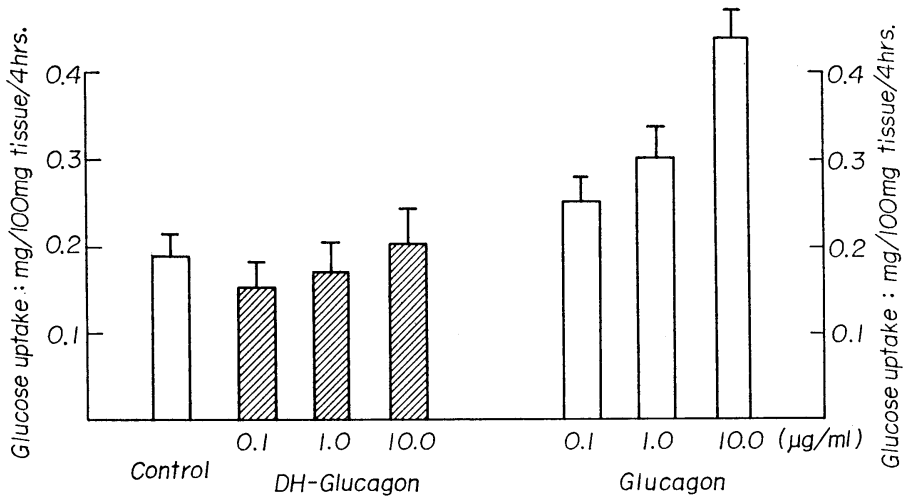

Values are the mean (土S.E.M.) of 12 experiments.

Table 1. Lipolytic activity of DH-glucagon

Glucagon は脂肪異化促進ホルモンの代表的なも In vitro test on isolated rat adipose tissue のである．ラット副辠脂を用いる in vitro の実験 でも, glucagon は著明な脂肪異化作用を示す。

表 1 の中段は glucagon を in vitro に添加した さいの Glycerol 放出を示したものである. glucagon $0.1 \mu \mathrm{g} / \mathrm{ml}$ 以上の濃度で副辠脂からの Glycerol 放出は有意に促進されている。

てれに対して,DH-glucagon の場合には $0.1 \mu \mathrm{g} / \mathrm{ml}$, $1.0 \mu \mathrm{g} / \mathrm{ml}, 10.0 \mu \mathrm{g} / \mathrm{ml}$ のいずれの濃度によつても, 対照と比較して, Glycerol 放出の有意な促進は認 められなかつた。

\begin{tabular}{c|c|c}
\hline \multicolumn{1}{c|}{ Sample } & $\begin{array}{c}\text { Goncentration } \\
\mu \mathrm{g} / \mathrm{ml}\end{array}$ & $\begin{array}{c}\text { Glycerol released } \\
\mu \mathrm{Mol} / \mathrm{g} / 4 \mathrm{hrs} .\end{array}$ \\
\hline \multirow{3}{*}{ DH-Glucogon } & 0.1 & 4.2 \\
& 1.0 & 4.7 \\
& 10.0 & 5.0 \\
\hline \multirow{3}{*}{ Glucagon } & 0.1 & 7.6 \\
& 1.0 & 9.8 \\
Control & 10.0 & 18.2 \\
\hline
\end{tabular}

Values are the mean of 12 experiments.

\section{実験成績に対する考察}

DH-glucagon は, one step の Edman degradition によつて, glucagon からそのN末端アミノ酸であ 
る Histidine をとりさつたものである.

Felts ら $(1969)^{2)}$ は, glucagon の構造と機能との関係について検討し，てのさい DH-glucagon が，in vitroにおける脂肪異化作用を欠如することを明らかにした．次いで Sundby $(1970)^{3)}$ は，DH-glucagon の 化学的性状, 生物活性, および免疫活性についてくわしく検討した. その結果, DH-glucagon は glucagon と比較して化学的性状, および生物活性が異なるてとを明らかにした. しかし免疫活性については両者に差 異がみられないという成績を示している。

DH-glucagon をラットの腹腔内に投与したさいの血糖上昇に対する効果，および in vitroにおけるラッ ト副睾脂への Glucose uptake と medium 中への Glycerol 放出におよぼす影響について検討した今回の 成績は，いずれも Felts ら $(1969)^{2)}$ ，および Sundby $(1970)^{3)}$ の成績と一致するものといえる.

1 コのアミノ酸がはずれているというととだけで，かくも見事に生物活性が消失するというととは，ホル モンの構造と機能を考えるさい極めて興味深い点である.

なお Sundby $(1960)^{3)}$ は DH-glucagon の生物活性に関して，インスリン分泌作用におよぼす効果にもふ れているが，ての点については現在検討中である.

\section{総括}

Glucagon からN末端ア アノ酸である Histidine をとりのぞいた Deshistidine-glucagon (DH-glucagon) そついて，その生物活性を in vivo と in vitro で, Native-glucagon のそれと比較検討した. DH-glucagon は NOVO 研究所より供与されたものである. 実験結果は以下の如くである.

1 ） DH-glucagon $(30 \mu \mathrm{g})$ はラットの腹腔内投与後の糖原分解による血糖上昇作用を欠如した.

2 ） DH-glucagon $(0.1 \mu \mathrm{g} \sim 10.0 \mu \mathrm{g} / \mathrm{ml})$ によるラット副辠丸脂肪組織の in vitro での Glucose uptake の 促進は認められなかつた。

3 ) 同様に DH-glucagon $(0.1 \mu \mathrm{g} \sim 10.0 \mu \mathrm{g} / \mathrm{ml})$ による in vitro における Glycerol 放出を指標とした脂 肪異化促進効果も glucagon のそれと比較して明らかに欠如した.

以上の成績より DH-glucagon の生物活性について考察した.

要旨は内分泌学会東部部会46年 6 月例会で発表した.

\section{参 考 文 献}

1）池田義雄：日本臨牀 $23: 964,1965$.

2) Feltz, P.W. M.E.G. Ferguson, K.A. Hagey, E.S. Stitt, \& W.M. Mitcrell Presented at the 5th Meeting of E.A.S.D. in Montpellior, 1969.

3) Sundby, F. : Presented at the 7th Congress of the International Diabetes Federation in Buenos Aires, 1970 